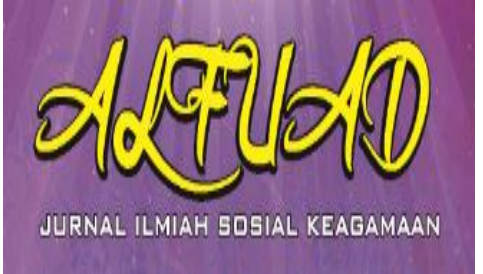

ALFUAD JOURNAL, 4 (2), 2020, (27-39)

(E-ISSN 2714-7606 P-ISSN 2614-4786 )

Available online at

http://ecampus.iainbatusangkar.ac.id/ojs/index.php/alfuad

\title{
PEMBANGUNAN MASYARAKAT ALTERNATIF MODEL DEMOCRATIC PARTICIPATORY
}

\section{Zainal Fadri}

Institut Agama Islam Negeri Batusangkar, Indonesia

E-mail: zainalfadri@iainbatusangkar.ac.id

\begin{abstract}
Development is a definite step undertaken by a country in achieving a good standard of living. Economic development and social development become a reflection of the success of the sovereign state so that it becomes a high bargaining value in international relations. Development in Brazil and Indonesia are both affected by the crisis that occurred in the world, thus presenting foreign entrapments and interventions that will affect every policy taken. To rise from the economic downturn, the state must be present in determining the right development model to overcome the problems that occur as a result of failure. The method used in this paper is the method of library research with a comparative analysis approach. Study material is taken from books and journals that are relevant to the theme of the writing. The results of this paper describe an alternative model of democratic participatory development into an effort to increase development, both in the social and economic fields. Community participation in development in Porto Alegre Brazil shows a significant change towards improving welfare, while at the same time being a lesson for Indonesia in making development policies optimally.
\end{abstract}

Keywords: Democratic, Participatory, Development, Society

\section{PENDAHULUAN}

Perselisihan antara negara-negara Blok Barat dan Blok Timur membawa dampak yang sangat besar terhadap perkembangan pembangunan negaranegara di dunia. Perang Dunia Pertama menjadikan beragam model kepentingan yang diluncurkan oleh negara-negara yang memiliki power, sehingga memunculkan beranekaragam model kebijakan dalam pergaulan internasional. Persoalan masih belanjut hingga Perang Dunia Kedua bahkan berakhirnya perang dingin yang diprakarsai oleh negara United State dan Uni Soviet sehingga terciptalah beberapa penggolongan kategori negara berdasarkan perkembangan yang dilakukan.

Negara-negara dklasifikasikan dengan memberi nama sebagai negara pertama, negara kedua dan negara ketiga. Negara pertama adalah negara-negara yang memiliki posisi serta kedudukan sentral, baik di bidang ekonomi maupun di bidang politik. Negara-negara tersebut seperti Amerika Serikat dan beberapa negara Eropa bagian Barat. Sementara untuk negara dunia kedua jatuh pada negaranegara yang berada di Eropa Timur dan sebagian Amerika Latin, serta negara dunia 
ketiga ditetapkan pada negara-negara yang berada di kawasan Asia dan Afrika.

Semenjak meletusnya Perang Dunia Kedua pada tahun 1939 dan berakhir pada 1945 seiring dengan meletusnya bom atom di kota Hiroshima dan Nagasaki Jepang, mengisyaratkan bahwa masing-masing negara mengibarkan bendera kemerdekan sehingga akan menjalani poros perekonomian sesuai dengan yang direncanakan oleh pemerintah terkait. Pasca Perang Dunia dan Perang Dingin antara Blok Barat dan Blok Timur, Indonesia mengambil kesempatan untuk merdeka secara politik dan disusul dengan merdeka secara ekonomi dan pengaturan kegiatan ekonomi.

Pasca kemerdekaan, negara Indonesia mengambil langkah pembangunan dalam bidang politik, terutama pada masa Orde Lama. Pembangunan politik yang diambil adalah keputusan yang tepat karena Indonesia baru saja merdeka sehingga pembangunan harus dilaksanakan serta penguatan kapasitas negara dari intervensi dan ancaman luar negeri terutama keputusan yang akan mempengaruhi kebijakan yang akan diambil. Pembangunan politik berjalan hingga runtuhnya kejayaan Orde Lama yang ditandai bergantinya rezim Orde Baru di bawah pimpinan Soeharto sebagai presiden ke dua Indonesia.
Pembangunan pada masa Orde Baru cenderung mengarah pada pembangunan ekonomi karena Indoensia dirasa sudah memiliki kapasitas dalam upaya meningkatkan taraf hidup masyarakat. Pembangunan ekonomi pada masa Orde Baru terkesan memaksakan perkembangan pertumbuhan ekonomi sebagai dampak dari rezim pemerintahan otoriter sehingga terjadi peningkatan yang signifikan di bidang ekonomi. Peningkatan yang paling nyata adalah ketika pemerintah mencanangkan bahwa pembangunan di Indonesia suadah mencapai tahap take off berdasarkan teori pertumbuhan yang pernah dikemukakan oleh Rostow, serta menempatkan Indonesia meninggalkan perekonomian tradisional dan akan menyusul model pembangunan industri layaknya negara dunia pertama atau negara maju.

$$
\text { Rostow dalam teorinya }
$$
mengungkapkan bahwa perkembangan pembangunan model teori pertumbuhan akan berlangsung ketika pembangunan suatu negara telah meninggalkan model perekonomian tradisional, baik di bidang usaha tradisi seperti agraris dan lain sebagainya. Masyarakat akan menuju tahap pra tinggal landas, tinggal landas dan berakhir pada kegiatan pembangunan modern yang ditandai kegiatan industri sebagai pembangunan di bidang ekonomi. Masyarakat modern dengan kegiatan 
industri sebagai pokok pembangunan ekonomi menjadikan beberapa negara berkembang atau negara dunia ketiga memiliki keinginan untuk segera meninggalkan perekonomian tradisional sehingga dapat mengejar ketertinggalan dari negara dunia pertama.

Persoalan yang melanda Indonesia pada zaman Orde Baru adalah pencanangan pembangunan yang telah mencapai tahap tinggal landas, padahal masih banyak persoalan Indonesia yang harus mendapat penyelesaian dari persoalan tersebut. Model perekonomian tradisional Indonesia dengan mengandalkan aktifitas agraris menempatkan posisi teori pertumbuhan Rostow menjadi suatu hal yang susah terwujud, dan bahkan akan dikhawatirkan terjadi loncatan tahapan yang akan berdampak buruk bagi Indonesia sediri.

Perkembangan ekonomi Indonesia mengalami krisis hebat ketika tahun 19871988, dimana krisis juga terjadi di beberapa belahan dunia termasuk negara Amerika Serikat. Krisis yang terjadi di Indonesia pada tahun itu dapat dikatakan sebagai berakhirnya rezim Orde Baru dan munculah masa Reformasi dengan berbagai persoalan yang harus segera diselesaikan. Perekonomian Indonesia pada masa peralihan ini mencapai titik paling lemah sehingga harus menyisakan hutang yang sangat banyak (Jefriando,
2013) termasuk dari Bank Dunia maupun IMF sebagai funding dunia internasional dalam membantu modal penanganan krisis moneter.

Hutang yang semakin banyak telah melibatkan Indonesia pada hubungan yang tidak dapat terlepas dari jeratan Bank Dunia dan IMF sehingga dibutuhkan suatu solusi dalam menjalankan poros perekonomian dan pembangunan yang ada di Indonesia. Bahkan per Juli tahun 2015, hutang Indonesia telah mencapai 4.376,3 Triliun Rupiah (Gumelar, 2015), atau hampir menyamai Anggaran Pendapatan dan Belanja Negara (APBN) Indonesia dalam satu periode. Keadaan ini menjadi suatu persoalan yang terus menjerat Indonesia sehingga banyak kebijakan yang diambil pemerintah Indonesia mengalami intervensi dari pihak asing, terutama mengenai modal pembangunan yang berasal dari pinjaman sebagai funding institution.

Persoalan-persoalan pembangunan dan keterlibatan pihak-pihak yang tidak menguntungkan Indoensia menjadi suatu landasan dalam tulisan ini sebagai bentuk suatu model alternatif pembangunan agar Indonesia dapat keluar dari jeratan lembaga-lembaga funding. Pada tulisan ini penulis tertarik dengan model pembangunan yang dilaksanakan di Brazil terutama di Porto Alegre. Porto Alegre merupakan salah satu kota di Brazil yang 
berhasil keluar dari kekalutan dan kerumitan model pembangunan yang berkembang di negara-negara Barat. Alasan pengambilan Porto Alegre Brazil, karena Brazil mengalami perkembangan perekonomian yang relatif sama dengan Indonesia dan memiliki bentangan alam yang sangat luas, bahkan Brazil pernah terpuruk dalam hutang kepada IMF ketika mengalami krisis. Brazil berhasil keluar dari jeratan hutang dan akhirnya mampu menjadi negara yang otonom baik dari segi ekonomi maupun pembangunan sosial untuk warga masyarakat. Dari tulisan ini nantinya diharapkan menemukan suatu pemahaman baru mengenai perkembangan yang telah dilakukan di Brazil sehingga dapat dijadikan sebagai prototype bagi negara-negara berkembang seperti Indonesia untuk melangkah dan menuju pembangunan sesuai dengan yang dicitacitakan.

\section{METODE}

Metode yang digunakan pada penelitian ini adalah kualitatif deskriptif. Penjabaran yang bersifat kualitatif digunakan untuk menganalisa materi dan pembahasan yang terdapat pada penelitian sehingga menghasilkan sebuah tinjauan yang komprehensif. Selain itu, untuk menggali data dan temuan, peneliti juga menggunakan perspektif perbandingan atas kategori yang dibahas. Dalam penelitian ini pembangunan alternatif di Porto Alegre dikomparasi dengan pelaksanaan konsep otonomi daerah di Indonesia, sehingga mencapai sebuah analisa bahwa konsep yang dibangun di dua tempat memiliki semangat yang sama, yaitu pembangunan masyarakat dengan asas demokrasi.

Penelusuran data pada penelitian ini menggunakan metode kepustakaan atau library research. Data yang ditemukan berupa penelitian dan gagasan yang berhubungan dengan pembangunan masyarakat dalam bentuk buku, jurnal maupun sumber lain yang relevan. Datadata yang telah didapatkan dianalisis dengan menggunakan beberapa tahap, yakni konfirmasi data dan komparasi yang menghasilkan sebuah pemikiran dan gagasan kritis dalam pembangunan masyarakat alternatif.

\section{PEMBAHASAN}

\section{Porto Alegre Rujukan Pembangunan Alternatif Democratic Participatory}

Porto Alegre merupakan kota metropolitan terbesar ke-empat yang ada di negara Brazil. Saat ini kota metropolitan Porto Alegre dijadikan sebagai benchmark untuk mengukur standar kualitas hidup dan keadaan lingkungan sosial, karena dianggap sebagai kehidupan kota yang lebih baik jika dibandingkan dengan beberapa kota yang lain. Pengakuan kondisi yang lebih baik dan lebih menunjang program pembangunan 
dibandingkan dengan kota lain, Porto Alegre menjadi pusat penyerapan investasi dari beberapa investor baik dari pemerintah maupun pihak swasta. Investasi yang berdatangan ke kota Porto Alegre berupa investasi di bidang pendidikan dan perumahan.

Pembangunan dan perbincangan yang menjadi topik hangat pada kegiatan kota Porto Alegre paling utama adalah di bidang transportasi, pendidikan dan kebudayaan, kesehatan dan kesejahteraan sosial, pembangunan ekonomi, serta organisasi kota dan pembangunan migran (Wagle, 2003: 3). Transportasi merupakan bentuk dan jalan dari perkembangan yang berkaitan dengan kegiatan ekonomi. Kegiatan ekonomi akan berjalan dengan baik apabila sarana transportasi telah berjalan dengan maksimal sehingga kemungkinan hambatan dalam hubungan suatu barang dan jasa menjadi minim. Pendidikan dan kebudayaan menjadi penting karena masyarakat Brazil terutama kota Porto Alegre meyakini pendidikan sebagai modal yang paling fundamental dalam menjalankan kegiatan baik yang bersifat ekonomi maupun dalam hubungan sosial. Pendidikan dan kebudayaan menunjukkan seseorang berperilaku dan memiliki pengetahuan sebagaimana yang harus dijalankan sebuah negara dalam rangka pembangunan model democratic patisipatory yang bersifat budgeting.
Kesehatan dan kesejahteraan diakui sebagai tujuan dari pembangunan yang ada di Porto Alegre Brazil. Kesehatan dan kesejahteraan merupakan suatu cita-cita pembangunan negara bangkit dari keterpurukan dan menjadi semangat bersama dalam menentukan arah kebijakan pembangunan. Sementara pengaturan kota dan pembangunan migran menjadi pembeda sekaligus ciri khas dari pembangunan yang terdapat di Porto Alegre. Pengaturan kota sebagai kota metropolitan membuat pemerintahan kota Porto Alegre sedikit mengeluarkan tenaga sehingga tercipta suatu tatanan kota yang baik dari segi fisik, kebijakan pembangunan, serta kegiatan ekonomi dan sosial masyarakat. Keberadaan kota Porto Alegre dengan berbagai keunggulan diyakini sebagai dampak dari pengaturan strategi yang baik dari pemerintah sebagai pemangku kepentingan terkait.

Partisipasi yang terjadi di kota Porto Alegre dan beberapa perkotaan di Brazil tidak terlepeas dari konstitusi yang dibuat oleh kalangan militer pada tahun 1967 yang kemudian digantikan oleh konstitusi tahun 1988. Partisipasi yang paling besar terlihat dari pelaksanaan pemilihan umum walikota secara langsung oleh warga masyarakat. Pemilihan walikota yang berlangsung di kota Porto Alegre menjadi simbol dari kebangkitan brazil dari beberapa program yang berhasil 
dijalankan sebagai hasil pembangunan ekonomi dan sosial. Keberhasilan Brazil dalam program-program tersebut mengangkat nama Amerika Latin dalam pergaulan internasional sebagai bentuk bukti penghargaan atas keberhasilan suatu pembangunan yang sebelumnya banyak mengalami kemunduran (Winarno, 2013: 266).

Dalam menentukan kebijakan di Porto Alegre terdapat tahapan berupa pleno yang tediri dari beberapa putaran, termasuk pada tahapan pemilihan walikota. Pleno dilakukan dua kali pada setiap tema yang akan diluncurkan sebagai upaya untuk mengumpulkan partisipasi masyarakat. Kemudian dari perwakilan masyarakat yang memiliki kedudukan atau dihormati untuk memobilisasi pemilihan daerah delegasi kemudian menghadirkan bentuk diskusi-diskusi mengenai kebijakan yang akan diambil. Walikota dan kalangan eksekutif akan meninjau rencana investasi tahun sebelumnya dan mendiskusikan rancangan untuk tahun-tahun berikutnya. Anggota dewan penganggaran partisipatif (COP) merupakan lembaga penganggar yang berasal dari kalangan masyarakat degan membiasakan diri terhadap pembiayaan kota, perdebatan kriteria serta alokasi sumberdaya (Wagle, 2003: 5).

Pembiayaan kota, perdebatan kriteria dan alokasi sumberdaya merupakan bentuk partsipasi budgeting yang dilakukan di Porto Alegre. Partisipasi budgeting dilakukan dengan asas demokrasi, yaitu masyarakat mengetahui alokasi dan penggunaan dana serta dapat berpartisipasi aktif untuk memberi masukan dan saran pembiayaan pembangunan. Masyarakat yang berperan aktif merupakan perwakilan yang telah dibentuk sehingga saran-saran dari masyarakat umum sebagai penerima dan pelaksana kebijakan menyampaikan pada perwakilan yang telah dibentuk sebagai delegasi dalam menentukan proses budgeting.

$$
\text { Citra publik mengenai }
$$
pastisipatory budgeting memperlihatkan proses partisipasi konkret yang bersifat demoratis (democratic partisipatory budgeting) yang efektif sebagai bentuk pelibatan masyarakat dalam pengambilan keputusan. Utzig (2002: 2) menyatakan proses partisipasi masyarakat di Porto Alegre telah mendorong berkembangnya masyarakat sipil yang berpartisipasi aktif dalam pengambilan keputusan mengenai arah pembangunan serta sebagai alat untuk mempromosikan model pembangunan kota yang memanfaatkan populasi dan layanan masyarakat. Selanjutnya model partisipasi ini menghasilkan dampak yang besar terhadap kinerja pemerintah, baik dalam pelayanan maupun dalam menunaikan kewajiban sebagai aparatur negara, serta yang paling penting model patisipasi dapat 
menekan kecurangan seperti korupsi di tingkat pemerintahan.

Partisipasi masyarakat dalam bentuk demokrasi dan budgeting membuahkan hasil pembangunan dengan model pembangunan alternatif yang memiliki prinsip-prinsip ethics dan mengandung unsur partisipatif yang tinggi dari kalangan masyarakat. Partisipasi budgeting merupakan suatu hubungan dalam pembicaraan formal antara masyarakat mengenai keputusan program pembangunan yang akan dibentuk dan dilaksanakan serta mempertimbangkan proses pembiayaan dan pengawasan yang akan diteruskan kepada pemerintah sebagai suatu studi dalam menurunkan berbagai kebijakan (Winarno, 2013: 267). Program yang telah diteruskan ke pemerintah diturunkan kembali ke masyarakat setelah mendapat pesetujuan sehingga keputusan mengenai suatu kebijakan dapat dilaksanakan sesuai dengan yang telah disepakati antara pemerintah dan masyarakat.

Masyarakat dengan didampingi pemerinah dalam suatu komunitas masyarakat sipil membentuk suatu tatanan nilai dan ethics sebagai suatu pijakan yang berpusat pada masyarakat. Demokrasi semacam ini merupakan suatu kunci keberhasilan yang diselenggarakan di Porto Alegre. Memposisikan masyarakat sipil sebagai sentral dari pembangunan dapat dikatakan sebagai bentuk publik sphere. Model pembangunan partisipatory di Porto Alegre Brazil (Un-Habitat dalam Winarno, 2013: 268) tidak hanya memberikan hak untuk berbicara, namun juga diberikan hak untuk didengar dan hak sebagai pertimbangan keputusan yang akan disepakati untuk suatu program pembangunan. Dalam hal ini partisipatory budgeting dimaknai sebagai suatu proses yang terdiri dari multidimensi yang terdiri dari transparansi keuangan, pastisipasi, hukum normatif, politik pemerintahan, gender, fleksibilitas, budaya plural serta fokus multietnis.

Aktor dari pembangunan model democratic partisipatory adalah masyarakat sipil sebagai penerima program sekaligus menjadi dewan pertimbangan program kebijakan. Dalam perumusan program melalui demokrasi memperlihatkan kekuatan dari kaum masyarakat sipil sebagai salah satu kunci penilaian keberhasilan suatu program yang diturukan oleh pemerintah selaku pemberi program. Hubungan yang demokratis antara masyarakat dan pemerintah akan memperlihatkan apakah suatu model democratic partisipatory berhasil dilaksanakan. Hubungan yang baik serta terbukanya transparansi mengenai budgeting dan lain sebagainya membuktikan keberhasilan model 
hubungan partisipatory civil society dalam pembangunan.

Model pembangunan democracy partisipatory membawa Porto Alegre pada tahap yang sangat baik dalam arena negara Brazil. Porto Alegre dapat menekan laju penduduk yang memberikan dampak perkembangan manajemen industrilaisasi di sekitar kota tersebut. Pada tahun 1997 masyarakat miskin Porto Alegre menduduki posisi paling rendah jika digabungkan dengan data penduduk miskin yang ada di Brazil (Minos dalam Winarno, 2013: 268). Kota Porto Alegre diberikan penghargaan sebagai kota dengan level pendidikan tertinggi dan sistem transportasi masal yang baik.

Keberhasilan Porto Alegre yang dapat dirasakan selama beberapa tahun semenjak diberlakukan sistem transparansi dan demokrasi partisipatif dalam pembangunan diantaramya (Un-Habitat dalam Winarno, 2013: 269): (1) Produksi perumahan sebanyak 439 unit per tahun (1973-1988) meningkat menjadi 1000 unit per tahun (1989-2003), (2) Peningkatan pengaspalan jalan dan perbaikan akses transportasi serta infrastruktur publik, terutama di wilayah Porto Alegre, (3) Peningkatan prosentase pemukiman yang dekat dengan sumber air meningkat sekita 94,7 persen pada tahun 1989 menjadi 99,5 persen pada tahun 2002, (4) Peningkatan jumlah sekolah publik dari 29 unit (dengan pendaftar sebanyak 17.862 siswa) pada tahun 1988, menjadi 84 unit (dengan pendaftar sebanyak 55.741 siswa) pada tahun 2002, (5) Memperioritaskan pengeluaran untuk pembelanjaan dan penunjang kesehatan sebesar 18 persen, serta (6) Mengembangkan program kesejahteraan sosial yang mencakup children and youth at risk, homeless people, victims of violence, low income family dan lain sebagainya.

Keberhasilan Porto Alegre dalam membangun suatu bentuk hubungan democracy partisipatory menggambarkan suatu langkah yang baik dalam mengelola dan mengendalikan arah pembangunan sosial guna peningkatan taraf hidup masyarakat. Penentuan kebijakan dengan model partisipasi dari masyarakat sipil merupakan suatu jalan dalam menampung dan menumbuhkan rasa saling percaya antara pemerintah dan masyarakat. Kebijakan suatu program pembangunan dilaksanakan dan diselenggarakan dengan transparan serta mengikutsertakan peran masyarakat dapat dijadikan contoh yang baik dalam menemukan model pembangunan yang tepat, terutama bagi negara dengan masyarakat besar seperti Indonesia. 
Otonomi Daerah dalam Pembangunan Masyarakat

Otonomi daerah sebagai bentuk desentralisasi merupakan bentuk suatu sistem penyerahan urusan pemerintahan serta pelimpahan wewenang kepada daerah yang berada di bawah kekuasaan suatu negara. Ciri-ciri hakikat otonomi yang independen yaitu legal self sufficiency dan actual independence. Dalam kaitannya dengan politik atau pemerintahan, otonomi daerah berarti self government atau the conditition of living under one's own laws (Chalid, 2005: 15). Otonomi lebih menitikberatkan aspirasi daripada kondisi. Otonomi daerah menjamin setiap daerah memiliki peluang yang sama untuk berkembang berdasarkan potensi yang ada. Potensi sumberdaya alam dan manusia menjadi perumusan secara optimal jika masing-masing daerah diberi keleluasaan dan jaminan untuk menentukan yang terbaik atas program yang akan dilaksanakan.

Otonomi daerah menurut UU No. 32 Tahun 2004 sesuai dari amandemen UU No. 22 Tahun 1999 diartikan sebagai hak, wewenang, dan kewajiban daerah otonom untuk mengatur dan mengurus sendiri urusan pemerintahan dan kepentingan masyarakat setempat sesuai dengan peraturan perund ang-und angan. Sedangkan desentralisasi adalah penyerahan wewenang pemerintah oleh Pemerintah kepala daerah otonomi untuk mengatur dan mengurus urusan pemerintahan dalam sistem Negara Kesatuan Republik Indonesia.

Secara politik, desentralisasi merupakan langkah menuju demokratisasi. Dengan desentralisasi, pemerintah lebih dekat dengan rakyat, sehingga kehadiran pemerintah lebih dirasakan oleh rakyat begitu pula keterlibatan rakyat dalam perencanaan, sehingga pelaksanaan serta pengawasan pembangunan dan semakin nyata. Secara sosial, desentralisasi akan mendorong masyarakat ke arah swakelola dengan memfungsikan pranata sosial yang merupakan social capital dalam menyelesaikan persoalan-persoalan yang dihadapi. Dengan pranata yang telah diinternalisasikan, mekanisme penyelesaian dipandang lebih efektif, efisien dan adil. Sedangkan secara ekonomi, desentralisasi diyakini dapat mencegah eksploitasi pemerintah pusat terhadap daerah, menumbuhkan inovasi masyarakat dan mendorong motivasi masyarakat untuk lebih produktif. Secara administratif akan mampu meningkatkan kemampuan daerah dalam melakukan perencanaan, pengorganisasian, meningkatkan akuntabilitas atau pertanggungjawaban publik.

Chalid (2005: 1) juga mengatakan bahwa sistem pemerintahan desentralisasi sebenarnya telah digagas oleh para pendiri 
negara yang tercantum pada pasal (18) UUD 1945. Implementasi pasal tersebut selalu menimbulkan persoalan sejak awal kemerdekaan. Pergulatan mencari makna kebangsaan yang dipandang sebagai identitas sekunder, selalu menghadapi persoalan identitas primer berupa kuatnya solidaritas etnik, agama, adat dan bahasa serta tradisi lokal. Faktor-faktor tersebut menyebabkan timbulnya pemberontakan kedaerahan selain faktor ketidakadilan dalam pembagian sumberdaya ekonomi antara Pusat dan Daerah. Sejak tahun 1945 Pemerintah Pusat memandang pluralitas secara ambivalen. Di satu sisi mempromosikan Bhinneka Tunggal Ika sebagai semboyan resmi negara, di sisi lain menerapkan kebijakan sentralisasi karena kebhinekaan dilihat sebagai ancaman disintegrasi.

Kendala dan tantangan yang dimunculkan oleh otonomi daerah sebagai bentuk desetralisasi pemerintahan mengharuskan pemerintah sebagai pengambil kebijakan dapat memberikan persiapan yang matang sebelum dilaksanakan sebagai program pembangunan. Dengan melihat tantangan yang ada memperlihatkan beberapa kepentingan yang harus ditunaikan agar menjadikan program otonomi daerah berjalan sesuai dengan yang diharapkan. Kepentingan otonomi daerah harus diwujudkan dalam bentuk politic quality, local accountability dan local responsiveness.

Politik quality, menekankan pelaksanaan desentralisasi dan otonomi daerah yang mengharapkan pembukaan kesempatan lebih bagi masyarakat untuk berpartisipasi dalam bebagai aktivitas politik ditingkat lokal. Local accountability dimaksudkan sebagai upaya peningkatan kemampuan pemerintah daerah dalam memperhatikan masyarakat. Local responsiveness, pemerintah daerah dianggap lebih banyak mengetahui berbagai masalah yang dihadapi oleh masyarakat, maka kebijakan desentralisasi dan otonomi daerah diharapkan akan mempermudah antisipasi terhadap berbagai masalah yang muncul dan sekaligus meningkatkan percepatan pembangunan sosial dan ekonomi.

Pada dasarnya, desentralisasi bertujuan membangun partisipasi masyarakat dan mengundang keterlibatan publik seluas-luasnya dalam proses perencanaan, implementasi dan evaluasi pembangunan yang dijalankan. Untuk itu, desentralisasi memberikan ruang yang lebih luas kepada daerah untuk secara demokratis mengatur pemerintahannya sendiri sebagai manifestasi dari cita-cita sistem desentralisasi. Tetapi, pelaksanaan sistem ini mendapatkan tantangan yang cukup besar. Kendala-kendala tersebut diantaranya adalah (Chalid, 2005: 6-7): (1) 
Mindset atau mentalitas aparat birokrasi yang belum berubah, (2) Hubungan antara institusi pusat dengan daerah belum optimal, (3) Sumberdaya manusia yang terbatas, (4) Pertarungan kepentingan yang berorientasi pada perebutan kekuasaan, penguasaan aset dan adanya semacam gejala powershift syndrom yang menghinggapi aparat pemerintah, dan (5) Keinginan pemerintah untuk menjadikan desa sebagai unit politik di samping unit sosial budaya, dimana desa memiliki tatanan sosial budaya yang otonom.

Di samping kendala-kendala yang ditemukan dalam pembangunan model otonomi daerah, pemerinah Indoesia harus tetap memperhatikan kemungkinan adanya ancaman dari luar yang lebih bersifat globalisasi. Globalisasi akan memunculkan beragam bentuk hubungan yang memberikan peluang kepada pemerintah lokal dalam menjalankan roda perekonomian. Winarno (2010: 323) menyatakan kemungkinan ancaman terhadap pelaksanaan otonomi daerah dilihat dari dua implikasi yaitu: (1) globalisasi neoliberalisme harus dilihat sebagai diskursus dominan yang berpengaruh dalam keputusan dan kebijakan politik, (2) imbas langsung dari globalisasi akan terlihat dalam kegiatan berupa masuknya perusahaan-perusahaan multinasional ke daerah pedesaan.
Perekonomian liberal senantiasa akan mempengaruhi kebijakan tingkat lokal sebagai ontomi daerah dengan berbagai upaya termasuk melemahkan aparat tingkat daerah dengan berbagai fasilitas. Banyak perusahaan-perusahaan multinasional yang telah merambah pada tingkat daerah sehingga pelaksanaan otomi daerah dengan harapan peningkatan kesejahteraan masyarakat tidak tercapai dengan maksimal. Masuknya perusahaanperusahaan ke level daerah juga meninggalkan kerusakan seperti terkikisnya sumberdaya alam (kasus pertambangan), kerusakan lingkungan serta terjadinya perubahan sosial sebagai dampak urbanisasi yang menjadikan rakyat semakin jauh dari kata sejahtera. Maraknya kasus eksploitasi menjadikan kebijakan otonomi daerah segera mendapat perhatian dan upaya penguatan serta evaluasi dari berbagai pihak terutama pemerintah sehingga dengan harapan tercapainya tujuan pembangunan secara optimal.

\section{KESIMPULAN}

Krisis yang melanda dunia internasional merupakan suatu tantangan bagi seluruh negara, baik negara maju maupun bagi negara berkembang. Pengaruh krisis sangat berdampak pada kegiatan perekonomian yang dilangsungkan suatu pemerintahan negara. Pengalaman krisis telah melahirkan banyak 
intervensi asing atas pengelolaan dan kebijakan terutama bagi negara-negara yang terkena dampak secara intens. Indonesia maupun Brazil merupakan contoh negara yang terdampak krisis sehingga banyak kemunduran yang terjadi di bidang pembangunan. Jeratan eknomi liberalisme kapitalisme menjadikan negara jatuh pada kondisi sangat buruk yang menyisakan banyak hutang luar negeri dalam jangka panjang.

Model pembangunan dengan pendekatan partisipasi masyarakat atau democratic partisipatory dapat menjadi sebuah solusi untuk kebangkitan negara dalam menghadapi berbagai persoalan pasca krisis. Kota Porto Alegre di Brazil telah membuktikan kelebihan dan peningkatan yang luar biasa dari pembangunan model partisipasi masyarakat bahkan dalam hal budgeting. Porto Alegre mendapatkan kondisi perubahan ekonomi yang sangat signifikan sehingga menjadikan kota tersebut sebagai percontohan bagi kota-kota lain di Brazil.

\section{Pembangunan model democratic} partisipatory sebenarnya juga terdapat dalam semangat otonomi daerah yang berupaya mengikutsertakan daerah dan masyarakat dalam perumusan kebijakan suatu pembangunan. Otonomi daerah memiliki peran penting dalam pembangunan Indonesia sebagai negara kepulauan yang memiliki adat dan tata aturan hidup yang beragam. Kelemahankelemahan yang dimiliki oleh sistem pembangunan otonomi daerah semestinya menjadi perhatian oleh berbagai pihak agar pembangunan Indonesia terus melangkah dan mencapai tujuan sesuai cita-cita bersama.

Pembangunan di Porto Alegre dan kebangkitan Brazil dari keterpurukan ekonomi menjadi suatu pembelajaran penting bagi pemerintah dan masyarakat Indonesia dalam melaksanakan pembangunan. Brazil berhasil keluar dari krisis karena dimotivasi oleh keinginan kuat untuk lepas dari hutang luar negeri dan intervensi asing terhadap pembangunan. Modal karakter kuat yang dimiliki pemimpin negara menjadi pondasi bagi kelancaran dan kedaulatan suatu pembangunan sehingga diharapkan kebijakan yang diturunkan dengan partisipasi berbagai pihak merupakan sarana dalam mencapai kesejahteraan bersama secara optimal dan seimbang.

\section{DAFTAR PUSTAKA}

Amanda, L. (2011). "Krisis Pembangunan di Indonesia", http://www.kompasiana.com/ 55301a716ea83411278b459j3. Diakses Tanggal 20 Februari 2020. Pukul 20:34 WIB.

Chalid, P. (2005). Otonomi Daerah: Masalah, Pemberdayaan dan Konflik. Jakarta: Kemitraan.

Cira, D. (2002). "Municipal Urban Service, Housing, and Land Markets," dalam Brazil: 
Equitable, $\quad$ Competitive, Sustainable. New York: The World Bank. hal. 461-499.

Fadri, Zainal. (2019). Upaya Penanggulangan Gelandangan

Dan Pengemis (Gepeng)

Sebagai Penyandang Masalah

Kesejahteraan Sosial (PMKS)

Di

Yogyakarta. Komunitas, 10(1),

1-19. 2019.

https://Doi.Org/10.20414/Komu nitas.V10i1.1070

Fadri, Zainal. (2019). Tabuik: Local Wisdom as an Alternative for Suppressing the Impact of Structural Change in Pariaman. Alfuad: Jurnal Sosial Keagamaan, 3(1). 97-109. 2019. http://d x.doi.org/10.31958/jsk.v3 i1.1488

Fadri, Zainal. (2020). Studi Terhadap Program Housing Bagi Kawasan Terdampak Perusahaan Tambang. Islamic Review: Jurnal Riset dan Kajian Keislaman, 9(2). 299-320. DOI: $10.35878 /$ ISLAMICREVI EW.V9I2.212

Gumelar, G. (2015). "Hutang Luar Negeri Ind onesia Per-Juli 2015," http://www.cnnindonesia.com/e konomi/20150920094113-7879808/bi-total-utang-luarnegeri-ri-rp-per-juli-2015/, Diakses Tanggal 24 Februari 2020, Pukul 17:00 WIB.

Jefriando, M. (2013). "Kelemahan Krisis pada Tahun 1997-1998", http://finance.detik.com/read/20 13/09/06/145944/235135/html Diakses Tanggal 26 Februari 2020, Pukul 15:33 WIB.
Nestary, N. (2014). Perkembagan Perekonomian di Negara Brazil. Pekanbaru: STIE Pelita Indonesia.

Pincus, J. R., \& Winters, J. (2004). Membongkar Bank Dunia. Jakarta: Penerbit Djambatan.

Utzig, J. E. (2002). "Participatory budgeting of Porto Alegre: a discussion in the light of the principle of democratic legitimacy and of the criterion of governance performance", http://siteresources.worldbank.or g/Utzigpaper.pdf

Wagle, S. (2003). "Case Study 2 - Porto Alegre, Brazil: Participatory Approaches in Budgeting and Public Expenditure Management", http://siteresources.worldbank.or g/sdn71.pdf

Winarno, B. (2010). Melawan Gurita Neoliberalisme. Jakarta: Penerbit Erlangga. . (2013). Etika Pembangunan. Yogyakarta: Center for Academic Publishing Studies (CAPS).

World Bank. (2004). Indonesia: Adverting an infrastructure Crisis. Jakarta: The World Bank Office Indonesia. 